\title{
Effect of amino acid biostimulant on the yield and nutraceutical potential of soybean
}

\author{
Slawomir Kocira ${ }^{1^{*}}$ \\ ${ }^{1}$ University of Life Sciences in Lublin, Faculty of Production Engineering, Akademicka 13, 20-950, Lublin, Poland. \\ "Corresponding author (slawomir.kocira@up.lublin.pl).
}

Received: 25 July 2018; Accepted: 2 November 2018; doi:10.4067/S0718-58392019000100017

\begin{abstract}
Advancement in crop cultivation technologies strives to increase the yield and improve the quality of crops under minimized threats posed to the natural environment. Application of biostimulants is a treatment which increases crop yield and quality particularly after plants exposure to stress conditions. The objective of the work was to determine changes in yield and nutraceutical potential of soybean (Glycine max [L.] Merr.) 'Atlanta' after application of biostimulant. A field experiment was conducted in three growing seasons (2014-2016). Terra Sorb Complex biostimulant was applied in the growing season in the form of single or double spraying in two concentrations $(0.3 \%$ and $0.5 \%)$. Number of biostimulant applications and its concentration modified yield and quality of crop and also the nutraceutical and antioxidative potential of soybean. Foliar application of biostimulant improved yield of soybean (increased by $25 \%$ compared to the control) without any negative effect on the nutritive value of seeds. The application of biostimulant increased (compared to the control) number of pods and seeds (32\%), plant height (38\%), phenolic content (34\%), flavonoids content (74\%), and reducing power (210\%). Taking into account biometric traits of soybean plants, positive effects were observed in the case of single biostimulant applications with lower concentration. The conducted study demonstrated a significant increase in the soybean yield and antioxidant potential after double application of the tested biostimulant at higher concentration. On the other hand, total fat and protein content was higher in plants treated once with a lower product concentration.
\end{abstract}

Key words: Antioxidant potential, biometric traits, fat, Glycine max, phenols, protein, soybean.

\section{INTRODUCTION}

Many research studies emphasize the suitability of biostimulants in the cultivation of many plants in the world (Calvo et al., 2014; Czerwinska and Szparaga, 2015; Kocira et al., 2015a; 2015b; 2015c; Koleska et al., 2017). Researchers primarily stress their impact on plant yielding. However, there is still little information about the effects of biostimulant treatments on the nutritional value and health-promoting potential of plant products (Michalak et al., 2016; Kocira et al., 2017a; 2018a). Stress can affect plant metabolism, which in turn leads to increased antioxidant properties (Zlotek et al., 2017). In addition, it was proven that biostimulants can also affect plant metabolism (Khan et al., 2009). The nutraceutical potential of plant products is primarily related to the presence and quantity of antioxidants. Bioactive compound contents and antioxidant potential depend on the types of biostimulants, their concentrations and number of applications (Kocira et al., 2017a).

The group of natural biostimulants includes preparations based on free amino acids, extracts from marine algae and fruits, effective microorganisms, and also humic compounds and chitosan (Calvo et al., 2014).

Among the natural biostimulants, worthy of special attention is "Terra Sorb Complex", which is characterized by a high (20\%) content of free amino acids synthesized via enzymatic hydrolysis which enables preserving their completeness and effectiveness. The amino acids in Terra Sorb Complex include: aliphatic amino acids (glycine, alanine, valine, leucine, 
isoleucine, proline), hydroxy-amino acids (serine, threonine), S-containing amino acids (cysteine, methionine), aromatic amino acids (phenylalanine, tryptophan, tyrosine), acidic amino acids (aspartic acid, glutamic acid), and basic amino acids (histidine, arginine, lysine) (Kocira et al., 2015a). Apart from the aforementioned organic compounds, Terra Sorb Complex contains also (in lower concentrations) organic N (5.0\%), B (1.5\%), $\mathrm{Mg}(0.8 \%), \mathrm{Fe}(1 \%), \mathrm{Zn}(0.1 \%), \mathrm{Mn}(0.1 \%)$, Mo $(0.001 \%)$, and many micro-elements (Kocira et al., 2015a). According to Oltenacu et al. (2017), such a composition of this biostimulant being rich in nutrients (organic matter content at 25\%), may ensure appropriately high rate of plants growth and their increased resistance to stress factors.

Due to the fact that there is little information in literature on the modification of the yield, nutraceutical, and antioxidant potential resulting from the use of biostimulant based on amino acids, the following research hypothesis was put forward: the yield of soybean and its quality depends on the doses and concentrations of the biostimulant. The objective of the work was to determine changes in yield and nutraceutical potential of soybean 'Atlanta' after application of biostimulant.

\section{MATERIALS AND METHODS}

Study material originated from a field experiment conducted in the years 2014-2016 in Perespa village (50 $66^{\prime} \mathrm{N} ; 2^{\circ} 63^{\prime}$ E), Poland, on soybean (Glycine $\max$ [L.] Merr.) 'Atlanta'. The experiment was established in a randomized block design in four replicates on experimental plots with area of $10 \mathrm{~m}^{2}$. Soybean was cultivated on the soil belonging to the Gleyic Phaeozems, characterized by alkaline $\mathrm{pH}$ ( $\mathrm{pH}$ in $1 \mathrm{M} \mathrm{KCl} \mathrm{7.4-7.5).} \mathrm{Soybean} \mathrm{seeds} \mathrm{were} \mathrm{sown} \mathrm{on} 25$ April 2014, 25 April 2015, and 23 April 2016 in rows every $30 \mathrm{~cm}$ at a raw spacing of $3.5 \mathrm{~cm}$. Temperature and rainfall during the soybean growing season 2014-2016 are presented in Table 1. In the growing season, plants were sprayed with biostimulant (water solutions) according to the scheme of doses, developmental stages of plants and terms of spraying as presented in Table 2. Plants sprayed with water served as the control. The biostimulant was applied at the BBCH 13-15 stage of soybean plants development, when foliar administration of microelement preparations is recommended to stimulate plant growth and development. The second spraying with the biostimulant was performed at the BBCH 61 stage of soybean plants development, i.e. at the beginning of blooming, because this is a critical period in their development (Kocira et al., 2018a). Two water solutions of Terra Sorb Complex ( $0.3 \%$ and $0.5 \%)$ were used in this study. Plants were sprayed with a biostimulant solution using a GARLAND FUM 12 B battery (Bricolemar S.L., Madrid, Spain) field sprayer at a constant pressure of $0.30 \mathrm{MPa}$, using $300 \mathrm{~L}$ solution per hectare.

Table 1. Temperature $(T)$ and rainfall $(R)$ during the soybean growing season 2014-2016.

\begin{tabular}{|c|c|c|c|c|c|c|c|c|}
\hline \multirow[b]{3}{*}{ Month } & \multicolumn{6}{|c|}{ Season } & & \\
\hline & \multicolumn{2}{|c|}{2014} & \multicolumn{2}{|c|}{2015} & \multicolumn{2}{|c|}{2016} & \multicolumn{2}{|c|}{ Average from 2002 to 2013} \\
\hline & $\mathrm{T}$ & $\mathrm{R}$ & $\mathrm{T}$ & $\mathrm{R}$ & $\mathrm{T}$ & $\mathrm{R}$ & $\mathrm{T}$ & $\mathrm{R}$ \\
\hline & ${ }^{\circ} \mathrm{C}$ & $\mathrm{mm}$ & ${ }^{\circ} \mathrm{C}$ & $\mathrm{mm}$ & ${ }^{\circ} \mathrm{C}$ & $\mathrm{mm}$ & ${ }^{\circ} \mathrm{C}$ & $\mathrm{mm}$ \\
\hline April & 9.4 & 36.5 & 8.2 & 30.1 & 9.2 & 68.4 & 8.5 & 41.2 \\
\hline May & 13.7 & 208.3 & 12.7 & 108.6 & 13.8 & 61.3 & 12.7 & 63.4 \\
\hline June & 16.1 & 67.1 & 17.4 & 14.1 & 18.1 & 97.1 & 17.7 & 68.6 \\
\hline July & 20.3 & 104.2 & 19.6 & 59.2 & 19.5 & 107.6 & 18.9 & 79.1 \\
\hline August & 18.2 & 115.4 & 21.6 & 23.4 & 18.2 & 95.3 & 19.4 & 71.8 \\
\hline September & 13.7 & 89.4 & 15.1 & 137.6 & 15.2 & 41.2 & 14.1 & 69.2 \\
\hline Average/Total & 15.1 & 620.9 & 15.8 & 373.0 & 17.1 & 470.9 & 15.2 & 393.3 \\
\hline
\end{tabular}

Table 2. Plant developmental stages and dates of Terra Sorb Complex treatment.

\begin{tabular}{|c|c|c|c|c|c|c|}
\hline \multirow{2}{*}{$\begin{array}{l}\text { Number of sprays and plant } \\
\text { developmental stages }\end{array}$} & \multirow[b]{2}{*}{ Concentration } & \multirow{2}{*}{$\begin{array}{l}\text { Combination } \\
\text { code }\end{array}$} & \multirow{2}{*}{$\begin{array}{c}\text { Volume of working } \\
\text { solution/working } \\
\text { pressure }\end{array}$} & \multicolumn{3}{|c|}{ Date of spraying } \\
\hline & & & & 2014 & 2015 & 2016 \\
\hline \multirow[t]{2}{*}{ Single spraying BBCH 13-15 } & $0.3 \%$ & $\mathrm{~T} 1$ & $300 \mathrm{~L} \mathrm{ha}^{-1} / 0.30 \mathrm{MPa}$ & 21 June & 20 June & 7 June \\
\hline & $0.5 \%$ & $\mathrm{~T} 2$ & & & & \\
\hline \multirow{2}{*}{$\begin{array}{l}\text { Double spraying BBCH 13-15, } \\
\text { BBCH } 61\end{array}$} & $0.3 \%$ & $\mathrm{~T} 3$ & $300 \mathrm{~L} \mathrm{ha}^{-1} / 0.30 \mathrm{MPa}$ & 21 June, 5 July & 20 June, 3 July & 7 June, 23 June \\
\hline & $0.5 \%$ & $\mathrm{~T} 4$ & & & & \\
\hline
\end{tabular}

BBCH: Biologische Bundesanstalt, Bundessortenamt and CHemical industry. 
Determinations were conducted for: seed yield, thousand seeds weight, as well as contents of protein and fat in DM of seeds. Protein content was determined with the Kjeldahl method (Distillation Unit K-350, BÜCHI Labortechnik AG, Flawil, Switzerland) (Official Method 992.23, 979.09; AOAC, 2000), whereas fat content on the acid hydrolysis method (Extraction System B-811, BÜCHI Labortechnik AG, Flawil, Switzerland) (Official Method 922.86; AOAC, 2000).

\section{Seed extract preparation}

Seed extract was prepared following the methodology proposed by Swieca et al. (2012). Soybean seeds were ground and extracted with a mixture of acetone, water and hydrochloric acid (70:29:1; v/v/v). Afterwards, samples were centrifuged for $10 \mathrm{~min}(6800 \mathrm{~g})$ and the resultant supernatant was collected and used for further analyses.

Content of total phenolic compounds (TPC) was determined with the method of Singleton and Rossi (1965) using the Folin-Ciocalteau reagent. Absorbance of the samples was measured with a UV-vis spectrophotometer at a wavelength of $725 \mathrm{~nm}$, then TPC was computed and expressed as a gallic acid equivalent (GAE) in $\mathrm{mg} \mathrm{g}^{-1} \mathrm{DM}$.

The total content of flavonoids was determined according to the method presented by Lamaison and Carnet (1990). The prepared soybean extract was mixed with a methanolic solution of $\mathrm{AlCl}_{3} \times 6 \mathrm{H}_{2} \mathrm{O}$. After incubation, absorbance was measured with a UV-vis spectrophotometer at the wavelength of $430 \mathrm{~nm}$. The total flavonoid content was expressed as a quercetin equivalent (QE) in $\mathrm{mg} \mathrm{g}^{-1} \mathrm{DM}$.

The content of anthocyanins was assayed with the method proposed by Fuleki and Francis (1968) using potassium chloride and sodium acetate buffer at two $\mathrm{pH}$ values (1.0 and 4.5). After $15 \mathrm{~min}$, absorbance of each sample was measured at wavelengths of 520 and $700 \mathrm{~nm}$. Then, anthocyanin content was calculated as a cynidin-3-glucoside equivalent (Cy3GE) in $\mathrm{mg} \mathrm{g}^{-1} \mathrm{DM}$.

Reducing power was measured following the method provided by Pulido et al. (2000). The soybean extract was mixed with a phosphate buffer and $\mathrm{K}_{3}\left[\mathrm{Fe}\left(\mathrm{CN}_{6}\right)\right]$. Next, samples were incubated at $50{ }^{\circ} \mathrm{C}$ for $20 \mathrm{~min}$. The reaction was stopped with trichloroacetic acid, and samples were centrifuged (6800 g, $10 \mathrm{~min})$. The resultant supernatant was mixed with distilled water and $\mathrm{FeCl}_{3}$. Then absorbance was measured at $700 \mathrm{~nm}$. Reducing power was expressed as a Trolox equivalent in $\mathrm{mg} \mathrm{g}^{-1} \mathrm{DM}$.

The obtained results were statistically elaborated with Statistica 13 software (StatSoft Inc., Tulsa, Oklahoma, USA). The materials were collected over three seasons (2014-2016). Laboratory analyses were performed in triplicate. Normality of data distribution was assessed with the Shapiro-Wilk test. The significance of differences between evaluated mean values was estimated with the Tukey test at a significance level of $\mathrm{p}<0.05$.

\section{RESULTS AND DISCUSSION}

The conducted study demonstrated a significant increase in the soybean yield after foliar application of the tested biostimulant (Tables 3 and 4). Kocira et al. (2018a) investigation also showed growth stimulation of soybean treated with a biostimulant containing free amino acids. Colla et al. (2014) confirmed that the use of a protein hydrolysate stimulated the growth of a pea stem, by acting similarly to gibberellins. The use of biostimulants caused also growth stimulation of many other plants, including legumes (Boghdady et al., 2016).

The experiment indicated that, application of biostimulants decreased weight of 1000 seeds. Similar observations were made by other authors who evaluated effects of various biostimulants on this trait, like an extract from seaweed in chickpea (Boghdady et al., 2016), mustard and pea (Matysiak and Kaczmarek, 2008) or Terra Sorb Complex in common bean 'Toska' (Kocira et al., 2015a).

Results of experiment indicated a distinct increase in the number of pods and seeds after foliar application of biostimulant. Similar findings were reported after the use of biostimulant, containing free amino acids and the extract from Ascophyllum nodosum, in soybean cultivation, including increased numbers of pods and seeds and an increased seed yield (Kocira et al., 2018a). Foliar application of the extract from Kappaphycus alvarezii (red algae) increased numbers of soybean pods and seeds (Rathore et al., 2009). Single application of the higher concentration of biostimulant ensured better effects in increasing soybean plant height (increased by $38 \%$ compared to the control) (Table 3 ). The highest plants were obtained in the growing season 2016 after their single spraying with the higher concentration of biostimulant. Results of experiment confirm earlier findings reported in soybean cultivation after treatments with the 
Table 3. Effect of biostimulant treatment on the yield and biometric traits of soybean.

\begin{tabular}{|c|c|c|c|c|c|c|c|}
\hline \multirow[b]{2}{*}{ Parameters } & \multirow[b]{2}{*}{ Season } & \multicolumn{5}{|c|}{ Biostimulant treatment } & \multirow[b]{2}{*}{ Mean } \\
\hline & & $\mathrm{T} 1$ & $\mathrm{~T} 2$ & $\mathrm{~T} 3$ & $\mathrm{~T} 4$ & Control variant & \\
\hline \multirow{4}{*}{ Seed yield, $\mathrm{t} \mathrm{ha}^{-1}$} & 2014 & $3.415 \pm 0.093 \mathrm{a}$ & $3.523 \pm 0.116 \mathrm{ab}$ & $3.780 \pm 0.099 b$ & $3.923 \pm 0.085 \mathrm{c}$ & $3.267 \pm 0.135 \mathrm{a}$ & $3.582 \pm 0.267 \mathrm{a}$ \\
\hline & 2015 & $3.705 \pm 0.083 b$ & $3.703 \pm 0.068 b$ & $3.650 \pm 0.174 b$ & $3.929 \pm 0.062 b$ & $2.664 \pm 0.218 \mathrm{a}$ & $3.230 \pm 0.496 \mathrm{a}$ \\
\hline & 2016 & $3.865 \pm 0.087 b$ & $3.919 \pm 0.146 b$ & $3.987 \pm 0.074 b$ & $4.084 \pm 0.155 b$ & $3.262 \pm 0.324 \mathrm{a}$ & $3.823 \pm 0.324 b$ \\
\hline & Mean & $3.639 \pm 0.228 \mathrm{~b}$ & $3.772 \pm 0.198 \mathrm{~b}$ & $3.881 \pm 0.170 \mathrm{bc}$ & $4.059 \pm 0.091 \mathrm{c}$ & $3.064 \pm 0.347 \mathrm{a}$ & - \\
\hline \multirow[t]{4}{*}{1000 seed weight, $g$} & 2014 & $169.2 \pm 5.5 \mathrm{a}$ & $161.6 \pm 5.2 \mathrm{a}$ & $163.9 \pm 4.4 \mathrm{a}$ & $165.1 \pm 2.1 \mathrm{a}$ & $182.2 \pm 3.5 b$ & $168.4 \pm 8.2 b$ \\
\hline & 2015 & $171.9 \pm 7.2 \mathrm{a}$ & $167.6 \pm 1.2 \mathrm{a}$ & $173.6 \pm 1.9 \mathrm{a}$ & $165.5 \pm 3.2 \mathrm{a}$ & $168.5 \pm 2.3 \mathrm{a}$ & $169.4 \pm 3.3 b$ \\
\hline & 2016 & $163.1 \pm 1.4 \mathrm{ab}$ & $160.2 \pm 3.9 \mathrm{a}$ & $166.0 \pm 1.7 \mathrm{bc}$ & $162.7 \pm 2.9 \mathrm{ab}$ & $171.0 \pm 1.4 \mathrm{c}$ & $164.6 \pm 4.1 \mathrm{a}$ \\
\hline & Mean & $165.6 \pm 4.5 \mathrm{a}$ & $162.2 \pm 3.9 \mathrm{a}$ & $164.4 \pm 5.1 \mathrm{a}$ & $164.3 \pm 1.5 \mathrm{a}$ & $173.9 \pm 7.3 \mathrm{~b}$ & - \\
\hline \multirow[t]{4}{*}{ Number of pods, Nr plant ${ }^{-1}$} & 2014 & $18.3 \pm 1.8 \mathrm{a}$ & $15.4 \pm 4.0 \mathrm{a}$ & $18.7 \pm 4.9 \mathrm{a}$ & $18.6 \pm 1.8 \mathrm{a}$ & $15.2 \pm 1.0 \mathrm{a}$ & $17.2 \pm 1.8 \mathrm{a}$ \\
\hline & 2015 & $22.3 \pm 1.1 \mathrm{c}$ & $16.0 \pm 0.7 \mathrm{ab}$ & $17.1 \pm 1.7 \mathrm{~b}$ & $21.2 \pm 0.8 \mathrm{c}$ & $14.7 \pm 0.5 \mathrm{a}$ & $18.3 \pm 3.3 \mathrm{a}$ \\
\hline & 2016 & $23.7 \pm 1.9 \mathrm{~b}$ & $21.8 \pm 0.7 \mathrm{~b}$ & $18.4 \pm 1.6 \mathrm{a}$ & $22.3 \pm 1.3 b$ & $16.3 \pm 1.5 \mathrm{a}$ & $20.5 \pm 3.1 \mathrm{~b}$ \\
\hline & Mean & $21.5 \pm 2.8 \mathrm{~b}$ & $19.5 \pm 3.5 \mathrm{~b}$ & $20.1 \pm 0.9 b$ & $20.4 \pm 1.9 \mathrm{~b}$ & $15.4 \pm 0.8 \mathrm{a}$ & - \\
\hline \multirow[t]{4}{*}{ Number of seeds, $\mathrm{Nr} \mathrm{m}^{-2}$} & 2014 & $2019 \pm 20 b$ & $2183 \pm 128 b c$ & $2308 \pm 89 \mathrm{~cd}$ & $2377 \pm 21 d$ & $1793 \pm 56 \mathrm{a}$ & $2136 \pm 235 a$ \\
\hline & 2015 & $2157 \pm 52 b$ & $2210 \pm 55 b$ & $2102 \pm 91 b$ & $2375 \pm 22 \mathrm{c}$ & $1581 \pm 112 \mathrm{a}$ & $2085 \pm 300 \mathrm{a}$ \\
\hline & 2016 & $2369 \pm 47 \mathrm{~b}$ & $2447 \pm 43 b$ & $2402 \pm 41 b$ & $2510 \pm 53 b$ & $1907 \pm 176 a$ & $2327 \pm 241 b$ \\
\hline & Mean & $2200 \pm 176 b$ & $2326 \pm 145 b c$ & $2362 \pm 153 \mathrm{c}$ & $2472 \pm 77 \mathrm{c}$ & $1760 \pm 165 \mathrm{a}$ & - \\
\hline \multirow[t]{4}{*}{ Plant height, $\mathrm{cm}$} & 2014 & $119.3 \pm 4.1 \mathrm{~b}$ & $120.8 \pm 4.9 \mathrm{~b}$ & $119.0 \pm 1.8 \mathrm{~b}$ & $113.1 \pm 9.7 b$ & $85.4 \pm 5.5 \mathrm{a}$ & $111.5 \pm 14.9 \mathrm{~b}$ \\
\hline & 2015 & $109.2 \pm 8.7 \mathrm{~b}$ & $101.4 \pm 2.2 \mathrm{~b}$ & $104.3 \pm 2.4 \mathrm{~b}$ & $102.3 \pm 2.4 \mathrm{~b}$ & $81.9 \pm 8.1 \mathrm{a}$ & $99.8 \pm 10.5 \mathrm{a}$ \\
\hline & 2016 & $116.2 \pm 1.5 \mathrm{~b}$ & $125.2 \pm 1.8 \mathrm{~b}$ & $119.3 \pm 3.5 b$ & $117.0 \pm 7.8 \mathrm{~b}$ & $88.1 \pm 7.4 \mathrm{a}$ & $113.2 \pm 14.4 \mathrm{~b}$ \\
\hline & Mean & $114.4 \pm 5.2 b$ & $117.5 \pm 12.7 \mathrm{~b}$ & $115.4 \pm 8.6 \mathrm{~b}$ & $112.7 \pm 7.6 \mathrm{~b}$ & $85.1 \pm 3.1 \mathrm{a}$ & - \\
\hline \multirow{4}{*}{$\begin{array}{l}\text { Number of internodes in the } \\
\text { main shoot }\end{array}$} & 2014 & $12.2 \pm 3.9 \mathrm{a}$ & $16.7 \pm 6.1 \mathrm{a}$ & $12.7 \pm 1.8 \mathrm{a}$ & $13.9 \pm 1.7 \mathrm{a}$ & $11.2 \pm 2.5 \mathrm{a}$ & $13.3 \pm 2.1 \mathrm{~b}$ \\
\hline & 2015 & $11.8 \pm 2.2 \mathrm{~b}$ & $9.6 \pm 1.3 \mathrm{ab}$ & $11.3 \pm 1.3 \mathrm{ab}$ & $8.1 \pm 0.5 \mathrm{a}$ & $10.1 \pm 2.1 \mathrm{ab}$ & $10.2 \pm 1.5 \mathrm{a}$ \\
\hline & 2016 & $15.0 \pm 6.3 \mathrm{a}$ & $15.7 \pm 3.2 \mathrm{a}$ & $13.9 \pm 3.0 \mathrm{a}$ & $11.9 \pm 0.6 \mathrm{a}$ & $9.6 \pm 2.1 \mathrm{a}$ & $13.2 \pm 2.5 b$ \\
\hline & Mean & $11.9 \pm 1.7 \mathrm{a}$ & $14.1 \pm 3.8 \mathrm{a}$ & $12.0 \pm 1.3 \mathrm{a}$ & $11.5 \pm 2.9 \mathrm{a}$ & $10.3 \pm 0.8 \mathrm{a}$ & - \\
\hline \multirow{4}{*}{$\begin{array}{l}\text { Location height of the first } \\
\text { pod, cm }\end{array}$} & 2014 & $13.3 \pm 2.0 \mathrm{a}$ & $12.5 \pm 2.1 \mathrm{a}$ & $12.8 \pm 1.7 \mathrm{a}$ & $13.5 \pm 1.9 \mathrm{a}$ & $12.5 \pm 1.6 \mathrm{a}$ & $12.9 \pm 0.5 \mathrm{a}$ \\
\hline & 2015 & $13.3 \pm 1.3 \mathrm{a}$ & $12.2 \pm 2.4 \mathrm{a}$ & $12.5 \pm 1.8 \mathrm{a}$ & $12.7 \pm 1.0 \mathrm{a}$ & $11.1 \pm 0.9 \mathrm{a}$ & $12.4 \pm 0.8 \mathrm{a}$ \\
\hline & 2016 & $13.8 \pm 2.2 \mathrm{a}$ & $11.7 \pm 1.0 \mathrm{a}$ & $13.8 \pm 2.0 \mathrm{a}$ & $13.8 \pm 1.8 \mathrm{a}$ & $11.7 \pm 0.7 \mathrm{a}$ & $13.0 \pm 1.2 \mathrm{a}$ \\
\hline & Mean & $13.8 \pm 0.3 b$ & $12.7 \pm 0.4 \mathrm{ab}$ & $13.0 \pm 0.7 \mathrm{ab}$ & $13.3 \pm 0.6 \mathrm{ab}$ & $11.7 \pm 0.7 \mathrm{a}$ & - \\
\hline
\end{tabular}

Means in the lines, concerning the selected traits, followed by different small letters are significantly different according to Tukey's test at $\mathrm{p}<0.05$.

extract from K. alvarezii (Rathore et al., 2009). The use of biostimulants caused also growth stimulation of many other plants, including legumes (Boghdady et al., 2016; Kocira et al., 2018a). The use of biostimulant containing amino acids resulted in an increase in the number of internodes on the main shoot. No reports are available in research literature on the effect of biostimulants on this trait. Results of experiment confirmed the stimulating effect of natural biostimulant Terra Sorb Complex also on the height of the first pod. A similar observation was made for a plant growth regulator preparation, containing polyphenols by Kozak et al. (2008).

In conducted study, the use of biostimulants determined protein content in soybean seeds. The positive effect of biostimulant on protein content in legume seeds was demonstrated by other authors in their experiments conducted on common bean (Zewail, 2014; Kocira et al., 2017b). The treatment of Fabaceae plants with biostimulants based on amino acids caused an increase in protein content in seeds of common bean (Zewail, 2014; Kocira et al., 2015b). However, some studies on the chemical composition of soybean seeds demonstrated a decreased content of protein after foliar application of biostimulant, containing free amino acids and the extract from A. nodosum (Kocira et al., 2018a). The application of the Terra Sorb Complex contributed to an increased fat content in soybean seeds. Investigations conducted so far on the effect of biostimulants on fat content in seeds have concerned rapeseed and showed a positive effect of Terra Sorb Foliar (Jakiene, 2013) on this trait. In contrast, Wójtowicz (2012) showed no effect of Terra Sorb Foliar on fat content in rapeseeds. In addition, considering that the mechanisms of action of the tested preparation have not been completely elucidated yet, one can try to hypothesize on the potential mechanisms of action of biostimulant to support explanation of results obtained in the experiment. The changes in total protein and fat content in soybean seeds are connected with 
Table 4. Effect of biostimulant treatment on the protein, fat content and antioxidative potential of soybean seeds.

\begin{tabular}{|c|c|c|c|c|c|c|c|}
\hline \multirow[b]{2}{*}{ Parameters } & \multirow[b]{2}{*}{ Season } & \multicolumn{5}{|c|}{ Biostimulant treatment } & \multirow[b]{2}{*}{ Mean } \\
\hline & & $\mathrm{T} 1$ & $\mathrm{~T} 2$ & $\mathrm{~T} 3$ & $\mathrm{~T} 4$ & Control variant & \\
\hline \multirow[t]{4}{*}{ Total protein, \% DM } & 2014 & $38.9 \pm 0.05 \mathrm{~d}$ & $35.2 \pm 0.60 \mathrm{a}$ & $37.7 \pm 0.04 \mathrm{c}$ & $36.2 \pm 0.03 b$ & $36.8 \pm 0.26 \mathrm{~b}$ & $37.0 \pm 1.42 \mathrm{~b}$ \\
\hline & 2015 & $49.3 \pm 0.04 \mathrm{e}$ & $47.8 \pm 0.03 \mathrm{~d}$ & $46.2 \pm 0.05 \mathrm{a}$ & $47.2 \pm 0.03 \mathrm{c}$ & $46.5 \pm 0.43 b$ & $47.4 \pm 1.23 \mathrm{c}$ \\
\hline & 2016 & $36.0 \pm 0.04 \mathrm{~b}$ & $34.6 \pm 1.05 \mathrm{a}$ & $36.6 \pm 0.03 b$ & $37.0 \pm 0.03 \mathrm{~b}$ & $35.9 \pm 0.46 \mathrm{ab}$ & $36.0 \pm 0.91 \mathrm{a}$ \\
\hline & Mean & $41.4 \pm 6.99 \mathrm{a}$ & $39.2 \pm 7.45 \mathrm{a}$ & $40.1 \pm 5.25 \mathrm{a}$ & $40.1 \pm 6.13 \mathrm{a}$ & $39.7 \pm 5.88 \mathrm{a}$ & - \\
\hline \multirow{4}{*}{ Total fat, \% DM } & 2014 & $16.3 \pm 0.03 b$ & $16.0 \pm 0.03 \mathrm{~b}$ & $16.2 \pm 0.04 \mathrm{~b}$ & $15.4 \pm 0.44 \mathrm{a}$ & $17.5 \pm 0.22 \mathrm{c}$ & $16.3 \pm 0.77 \mathrm{~b}$ \\
\hline & 2015 & $14.8 \pm 0.03 \mathrm{~d}$ & $13.5 \pm 0.02 b$ & $14.5 \pm 0.03 \mathrm{c}$ & $13.3 \pm 0.02 \mathrm{a}$ & $15.0 \pm 0.17 \mathrm{e}$ & $14.2 \pm 0.77 \mathrm{a}$ \\
\hline & 2016 & $16.9 \pm 0.02 b$ & $16.1 \pm 0.03 \mathrm{ab}$ & $16.9 \pm 0.06 \mathrm{~b}$ & $15.0 \pm 1.01 \mathrm{a}$ & $16.6 \pm 0.31 b$ & $16.3 \pm 0.80 \mathrm{~b}$ \\
\hline & Mean & $16.0 \pm 1.08 \mathrm{ab}$ & $15.2 \pm 1.47 \mathrm{ab}$ & $15.9 \pm 1.23 \mathrm{ab}$ & $14.5 \pm 1.12 \mathrm{a}$ & $16.4 \pm 1.27 \mathrm{~b}$ & - \\
\hline \multirow[t]{4}{*}{ TPC, $\mathrm{mg} \mathrm{g}^{-1} \mathrm{DM}$} & 2014 & $5.69 \pm 0.02 \mathrm{a}$ & $9.01 \pm 0.04 \mathrm{~d}$ & $7.34 \pm 0.04 \mathrm{c}$ & $10.66 \pm 0.02 \mathrm{e}$ & $5.77 \pm 0.07 \mathrm{~b}$ & $7.69 \pm 2.14 b$ \\
\hline & 2015 & $4.91 \pm 0.03 \mathrm{~d}$ & $6.77 \pm 0.02 \mathrm{e}$ & $4.35 \pm 0.03 \mathrm{a}$ & $4.65 \pm 0.06 \mathrm{c}$ & $4.50 \pm 0.03 b$ & $5.04 \pm 0.99 \mathrm{a}$ \\
\hline & 2016 & $5.94 \pm 0.03 b$ & $9.11 \pm 0.01 \mathrm{~d}$ & $7.29 \pm 0.01 \mathrm{c}$ & $11.24 \pm 0.03 \mathrm{e}$ & $5.77 \pm 0.01 \mathrm{a}$ & $7.87 \pm 2.31 \mathrm{c}$ \\
\hline & Mean & $5.31 \pm 0.54 \mathrm{a}$ & $8.30 \pm 1.32 \mathrm{bc}$ & $6.33 \pm 1.71 \mathrm{ab}$ & $8.85 \pm 0.42 c$ & $5.35 \pm 0.32 \mathrm{a}$ & - \\
\hline \multirow{4}{*}{ TFC, $\mathrm{mg} \mathrm{g}^{-1} \mathrm{DM}$} & 2014 & $3.35 \pm 0.03 \mathrm{~d}$ & $2.64 \pm 0.04 \mathrm{c}$ & $2.29 \pm 0.03 b$ & $3.71 \pm 0.03 \mathrm{e}$ & $1.99 \pm 0.03 \mathrm{a}$ & $2.80 \pm 0.72 \mathrm{a}$ \\
\hline & 2015 & $1.95 \pm 0.01 \mathrm{~b}$ & $4.24 \pm 0.03 \mathrm{~d}$ & $4.24 \pm 0.03 \mathrm{~d}$ & $3.01 \pm 0.02 \mathrm{c}$ & $1.44 \pm 0.03 \mathrm{a}$ & $2.98 \pm 1.29 \mathrm{c}$ \\
\hline & 2016 & $3.65 \pm 0.03 \mathrm{~d}$ & $2.79 \pm 0.01 \mathrm{c}$ & $2.13 \pm 0.03 \mathrm{~b}$ & $3.77 \pm 0.01 \mathrm{e}$ & $1.99 \pm 0.03 \mathrm{a}$ & $2.87 \pm 0.83 \mathrm{~b}$ \\
\hline & Mean & $2.98 \pm 0.91 \mathrm{~b}$ & $3.22 \pm 0.88 \mathrm{~b}$ & $2.89 \pm 1.17 \mathrm{~b}$ & $3.50 \pm 0.42 b$ & $1.81 \pm 0.32 \mathrm{a}$ & - \\
\hline \multirow[t]{4}{*}{ TAC, $\mathrm{mg} \mathrm{g}^{-1} \mathrm{DM}$} & 2014 & $0.00 \pm 0.000 \mathrm{a}$ & $0.01 \pm 0.001 \mathrm{~b}$ & $0.02 \pm 0.002 \mathrm{c}$ & $0.02 \pm 0.001 \mathrm{c}$ & $0.00 \pm 0.000 \mathrm{a}$ & $0.010 \pm 0.010 \mathrm{a}$ \\
\hline & 2015 & $0.07 \pm 0.001 \mathrm{c}$ & $0.01 \pm 0.003 b$ & $0.00 \pm 0.000 \mathrm{a}$ & $0.00 \pm 0.000 \mathrm{a}$ & $0.00 \pm 0.000 \mathrm{a}$ & $0.016 \pm 0.030 \mathrm{~b}$ \\
\hline & 2016 & $0.00 \pm 0.000 \mathrm{a}$ & $0.02 \pm 0.001 \mathrm{~b}$ & $0.02 \pm 0.001 \mathrm{~b}$ & $0.02 \pm 0.002 \mathrm{~b}$ & $0.00 \pm 0.000 \mathrm{a}$ & $0.012 \pm 0.011 \mathrm{a}$ \\
\hline & Mean & $0.023 \pm 0.040 \mathrm{~b}$ & $0.013 \pm 0.006 \mathrm{ab}$ & $0.013 \pm 0.012 \mathrm{ab}$ & $0.013 \pm 0.012 \mathrm{ab}$ & $0.000 \pm 0.000 \mathrm{a}$ & - \\
\hline \multirow[t]{4}{*}{$\mathrm{RP}, \mathrm{mg} \mathrm{g}^{-1} \mathrm{DM}$} & 2014 & $0.33 \pm 0.005 b$ & $0.59 \pm 0.005 \mathrm{~d}$ & $0.51 \pm 0.084 \mathrm{c}$ & $0.64 \pm 0.049 \mathrm{~d}$ & $0.15 \pm 0.010 \mathrm{a}$ & $0.45 \pm 0.202 b$ \\
\hline & 2015 & $0.19 \pm 0.005 \mathrm{a}$ & $0.18 \pm 0.005 \mathrm{a}$ & $0.10 \pm 0.004 \mathrm{a}$ & $0.20 \pm 0.005 \mathrm{a}$ & $0.10 \pm 0.005 \mathrm{a}$ & $0.15 \pm 0.050 \mathrm{a}$ \\
\hline & 2016 & $0.36 \pm 0.005 b$ & $0.57 \pm 0.005 \mathrm{~d}$ & $0.52 \pm 0.005 \mathrm{c}$ & $0.63 \pm 0.006 \mathrm{e}$ & $0.15 \pm 0.004 \mathrm{a}$ & $0.46 \pm 0.193 b$ \\
\hline & Mean & $0.29 \pm 0.091 \mathrm{ab}$ & $0.45 \pm 0.231 b$ & $0.38 \pm 0.240 \mathrm{~b}$ & $0.49 \pm 0.251 \mathrm{~b}$ & $0.13 \pm 0.029 \mathrm{a}$ & - \\
\hline
\end{tabular}

Means in the lines, concerning the selected traits, followed by different small letters are significantly different according to Tukey's test at $\mathrm{p}<0.05$. TPC: Total phenolics content; TFC: total flavonoids content; TAC: total anthocyanin content; RP: reducing power.

increased metabolism of $\mathrm{N}$ and $\mathrm{Fe}$, caused by biostimulants application. Their positive impact on plant metabolism is indicated by enhanced synthesis and activity of phytohormones and by stimulated growth and development of roots, which contributes to better uptake, translocation and retention of macro- and micro-elements as well as determines crop size and quality (Kocira et al., 2018b; Calvo et al., 2014). The foliar application of biostimulants has a positive effect on physiological processes ongoing in plants, by contributing to the improvement in their growth and development and also by increasing the size and quality of produced crop, which is ascribed to the presence of phytohormones or lowmolecular compounds (Tarakhovskaya et al.,2007) or to the presence of specific peptides and precursors of phytohormone biosynthesis (like tryptophan) (Colla et al., 2014), or to the stimulation of the activity of selected enzymes (catalase, peroxidase, lipoxygenase, nitrate reductase), enhancement of the activity of ferric ions in cells, synthesis of assimilation pigments and a higher rate of nutrients uptake (Halpern et al., 2015), or to the promoted activity of naturally-synthesized auxins as a result of enhanced inhibition of indoleacetic acid (IAA) oxidase (Haroun et al., 2011; Michalek et al., 2018) in the biostimulants.

The application of Terra Sorb Complex biostimulant, composed mainly of free amino acids, resulted in increased TPC content of the analyzed soybean seeds (Table 4).

As reported by Ertani et al. (2013), enhanced synthesis of antioxidative compounds, being indicators of increased plants resistance to various stress factors, is due to the effects of biostimulants. However, as proved in the study, their effects are attributed mostly to their composition. The physiological response of plants to the applied biostimulants results mainly from the presence of many so-called activating compounds which include, e.g., hormones, proteins, amino acids, phenols or triacontanol (Ertani et al., 2013). The conducted experiment proved also that the content of phenolic compounds in seeds depended on the concentration and number of applications of the analyzed biostimulants. 
A better effect, on average, was observed after double spraying the plants with their higher concentrations. In turn, according to Kaufmann et al. (2007), the highest effectiveness of biostimulants in crop cultivation was reported after the use of their minimal doses, however they pointed out that this effectiveness was mostly determined by the species and cultivar of plants and by plant growth stage. Experiments conducted by Ertani et al. (2013) proved also that differences in effects of biostimulants were due to the number of treatments at the appropriate BBCH stages (Meier, 2001).

The total content of flavonoids in seeds of plants treated with Terra Sorb preparation was significantly higher compared to the control. However, statistical analysis showed nonsignificant differences in their content as affected by the number of biostimulant applications. The observed increase in flavonoids, evoked by biostimulants, consequently led to an increased antioxidative potential and free radical scavenging power of the crop. This is also linked with mechanisms of plants response under stress conditions and with the accumulation of reactive oxygen species (ROS). Hence, plants response to the use of biostimulants is mainly due to their composition, molecular conformation and weight (Bulgari et al., 2015). Additionally biostimulants activates also defense mechanisms of plants, owing to which they may cope with the oxidative stress by enhancing the activity of enzymes of their antioxidative system and by increasing their total antioxidative capability (Szparaga et al., 2018; Djanaguiraman et al., 2004; 2005; 2009). The above changes occur as a result of increased enzymatic activity (catalase, CAT; superoxide dismutase, SOD) (Navabpour et al., 2003; Zimmermann and Zentgraf, 2005; Dai et al., 2017). The increased content of flavonoids results, most of all, from changes in the activity of phenylalanine ammonia lyase (PAL), which takes part in the biosynthesis of phenylpropanoids. As reported by Huang et al. (2010), a gene responsible for protein encoding in enzymes is susceptible to various abiotic and biotic stress factors in plants.

Foliar application of Terra Sorb Complex preparation had a significant effect on anthocyanins content in soybean seeds (Table 4). The highest content of these compounds was determined after single spraying the plants with its lower concentration. No differences were noted in soybean plants response to other combinations with Terra Sorb Complex biostimulant. This nutraceutical trait of seeds was additionally affected by the growing season and conditions occurring in it. According to Molmann et al. (2015), the content of phenolic compounds is determined by weather conditions occurring during vegetation. Its higher values were reported in the years with higher temperatures (Table 1).

Significant differences in the reducing power (RP) of soybean were also noted under the influence of Terra Sorb Complex biostimulant. The highest RP value (over 3.6-fold higher than control) was determined after plants spraying with its $0.5 \%$ solution. In the second study year, the value of RP was significantly lower than in the other analyzed years due to meteorological conditions. Investigations conducted by Ochoa-Velasco et al. (2016) showed the higher RP to be caused by increased contents of phenolic compounds, anthocyanins and flavonoids. Shan et al. (2012) demonstrated also that the value of the free radical scavenging power was mainly due to the increased content of flavonoids. It needs to be emphasized that the reducing potential is associated with the ratio of compounds being donors of $\mathrm{H}$ and capable of disrupting the free-radical chain. The increased value of RP due to plants treatments with biostimulants, determined in our study, is consistent with findings from the research conducted by Koleska et al. (2017), who evaluated the antioxidative activity in tomato plants treated with a biostimulant based on free amino acids. In turn, the experiment carried out by Sidhu et al. (2017) showed that tomatoes treated with a biostimulant in the form of a seaweed extract were characterized by a decreased reducing power compared to the control, irrespective of cultivar.

For all analyzed combinations of plants treatment with the tested biostimulant, it was concluded that the content of these bioactive compounds was influenced by weather conditions in the growing period. It needs to be emphasized that unbeneficial conditions appearing during the growth of plants induce their multiple defense systems. Under such circumstances, plants tend to save energy and water reserves, and their vital functions are supported from their own reserves. The occurrence of stress factors in the growing period leads to physiological changes in plants which close their stomata to prevent moisture loss and to retard the process of photosynthesis, which consequently leads to the inhibition of metabolic processes (Lakhdar et al., 2010). Providing an additional source of amino acids to plants through the application of biostimulants facilitates the opening of stomata whose function was disturbed by adverse environmental factors. The use of preparations based on free amino acids in plant cultivation facilitates water retention in plants, thereby stimulating photosynthesis and also the rate and direction of metabolic processes (Jakiene, 2013).

Significant differences in the RP of soybean were also noted under the influence of Terra Sorb Complex biostimulant. Investigations conducted by Ochoa-Velasco et al. (2016) showed the higher RP to be caused by increased contents of phenolic compounds. 


\section{CONCLUSIONS}

The number of biostimulant applications and its concentration modified the yield, as well as nutraceutical and antioxidative potential of soybean seeds. Yield and antioxidant activity of soybeans seeds after the biostimulator application was significantly different from the control. Taking into account biometric traits of soybean plants, positive effects were observed in the case of biostimulant applications with lower concentration. On the other hand, fat and protein content was higher in plants treated once with a lower product concentration. In addition, it was found that double spraying the plants with a biostimulant at a higher concentration, caused the increase of the antioxidant potential of soybeans. Analysis of results obtained in the experiment demonstrated that the crop productivity and its quality, were determined not only by the biostimulant application, but also by environmental conditions occurring in the growing season. The observed differences in obtained results can be due to changes in average air temperature and precipitation in particular years of the field experiment, which appeared to be stress factors to plants.

In the light of the conducted research, the application of biostimulant Terra Sorb Complex in 'Atlanta' soybean cultivation brought measurable results in the form of increased yield and modified nutraceutical and antioxidative potential soybean seeds. In agricultural practice, a double spraying of the plants with a biostimulant containing free amino acids at a higher concentration is recommended.

\section{ACKNOWLEDGEMENTS}

Research supported by the Ministry of Science and Higher Education of Poland as part of the statutory activities of the University of Life Sciences in Lublin.

\section{REFERENCES}

AOAC. 2000. Official methods of analysis of AOAC International. Horwitz, W. (ed.) $17^{\text {th }}$ ed. Association of Official Analytical Chemists (AOAC) International, Gaithersburg, Maryland, USA.

Boghdady, M.S., Selim, D.A.H., Nassar, R.M.A., and Salama, A.M. 2016. Influence of foliar spray with seaweed extract on growth, yield and its quality, profile of protein pattern and anatomical structure of chickpea plant (Cicer arietinum L.) Middle East Journal of Applied Sciences 6:207-221.

Bulgari, R., Cocetta, G., Trivellini, A., Vernieri, P., and Ferrante, A. 2015. Biostimulants and crop responses: a review. Biological Agriculture and Horticulture 31:1-17. doi:10.1080/01448765.2014.964649.

Calvo, P., Nelson, L., and Kloepper, J.W. 2014. Agricultural uses of plant biostimulants. Plant and Soil 383:3-41. doi:10.1007/s11104-014-2131-8.

Colla, G., Rouphael, Y., Canaguier, R., Svecova, E., and Cardarelli, M. 2014. Biostimulant action of a plant-derived protein hydrolysate produced through enzymatic hydrolysis. Frontiers in Plant Science 5:448. doi:10.3389/fpls.2014.00448.

Czerwinska, E., and Szparaga, A. 2015. Antibacterial and antifungal activity of plant extracts. Rocznik Ochrona Srodowiska 17:209-229.

Dai, L.Y., Zhu, H.D., Yin, K.D., Du, J.D., and Zhang, Y.X. 2017. Seed priming mitigates the effects of saline-alkali stress in soybean seedlings. Chilean Journal of Agricultural Research 77:118-125. doi:10.4067/S0718-58392017000200118.

Djanaguiraman, M., Devi, D.D., Sheeba, J.A., Bangarusamy, U., and Babu, C. 2004. Effect of oxidative stress on abscission of tomato fruits and its regulation by nitrophenols. Tropical Agricultural Research 16:25-36.

Djanaguiraman, M., Sheeba, J.A., Devi, D.D., and Bangarusamy,U. 2005. Effect of Atonik seed treatment on seedling physiology of cotton and tomato. Journal of Biological Science 5(2):163-169. doi:10.3923/jbs.2005.163.169.

Djanaguiraman, M., Sheeba, J.A., Devi, D.D., and Bangarusamy, U. 2009. Cotton leaf senescence can be delayed by nitrophenolate spray through enhanced antioxidant Demence system. Journal of Agronomy and Crop Science 195:213-224. doi:10.1111/j.1439-037X.2009.00360.x.

Ertani, A., Pizzeghello, D., Altissimo, A., and Nardi, S. 2013. Use of meat hydrolyzate derived from tanning residues as plant biostimulant for hydroponically grown maize. Journal of Plant Nutrition and Soil Science 176:287-296. doi:10.1002/jpln.201200020.

Fuleki, T., and Francis, F.J. 1968. Quantitative methods for anthocyanins. 1. Extraction and determination of total anthocyanin in cranberries. Journal of Food Science 33:72-77. doi:10.1111/j.1365-2621.1968.tb00887.x.

Halpern, M., Bar-Tal, A., Ofek, M., Minz, D., Muller, T., and Yermiyahu, U. 2015. The use of biostimulants for enhancing nutrient uptake. Sparks, D.L. (ed.) Advances in Agronomy 129:141-174. 
Haroun, S.A., Shukry, W.M., Abbas, M.A., and Mowafy, A.M. 2011. Growth and physiological responses of Solanum lycopersicum to Atonik and benzyl adenine under vernalized conditions. Journal of Ecology and the Natural Environment 3(9):319-331.

Huang, B., Ban, X., He, J., Zeng, H., Zhang, P., and Wang, Y. 2010. Hepatoprotective and antioxidant effects of the methanolic extract from Halenia elliptica. Journal of Ethnopharmacology 131:276-281 . doi:10.1016/j.jep.2010.06.029.

Jakiene, E. 2013. The effect of the microelement fertilizers and biological preparation Terra Sorb Foliar on spring rape crop. Zemes Ukio Mokslai 20:75-83. doi:10.6001/zemesukiomokslai.v20i2.2687.

Kaufmann, G.L.III., Kneivel, D.P., and Watschke, T.L. 2007. Effects of a biostimulant on the heat tolerance associated with photosynthetic capacity, membrane thermostability, and polyphenol production of perennial ryegrass. Crop Science 47:261267. doi:10.2135/cropsci2006.03.0171.

Khan, W., Rayirath, U.P., Subramanian, S., Jithesh, M.N., Rayorath, P., Hodges, D.M., et al. 2009. Seaweed extracts as biostimulants of plant growth and development. Journal of Plant Growth Regulation 28:386-399.

Kocira, A., Czerwinska, E., Tomkiewicz, D., and Kornas, R. 2018b. Ocena mikrobiologiczna nasion trzech odmian soi po zastosowaniu biostymulatora. Rocznik Ochrona Srodowiska 20:1710-1726.

Kocira, S., Kocira, A., Kornas, R., Koszel, M., Szmigielski, M., Krajewska, M., et al. 2017b. Effects of seaweed extract on yield and protein content of two common bean (Phaseolus vulgaris L.) cultivars. Legume Research 41(4):589-593. doi:10.18805/LR-383.

Kocira, A., Kocira, S., and Stryjecka, M. 2015b. Effect of Asahi SL application on common bean yield. Agriculture and Agricultural Science Procedia 7:103-107. doi:10.1016/j.aaspro.2015.12.045.

Kocira, A., Kocira, S., Swieca, M., Zlotek, U., Jakubczyk, A., and Kapela, K. 2017a. Effect of foliar application of a nitrophenolate-based biostimulant on the yield and quality of two bean cultivars. Scientia Horticulturae 214:76-82. doi:10.1016/j.scienta.2016.11.021.

Kocira, S., Kocira, A., Szmigielski, M., Piecak, A., Sagan, A., and Malaga-Tobola, U. 2015a. Effect of an amino acids-containing biostimulator on common bean crop. Przemysl Chemiczny 94:1732-1736. doi:10.15199/62.2015.10.16.

Kocira, S., Sujak, A., Kocira, A., Wójtowicz, A., and Oniszczuk, A. 2015c. Effect of Fylloton application on photosynthetic activity of Moldavian dragonhead (Dracocephalum moldavica L.) Agriculture and Agricultural Science Procedia 7:108-112. doi:10.1016/j.aaspro.2015.12.002.

Kocira, S., Szparaga, A., Kocira, A., Czerwinska, E., Wójtowicz, A., Bronowicka-Mielniczuk, U., et al. 2018a. Modeling biometric traits, yield and nutritional and antioxidant properties of seeds of three soybean cultivars through the application of biostimulant containing seaweed and amino acids. Frontiers in Plant Science 9:388. doi:10.3389/fpls.2018.00388.

Koleska, I., Hasanagic, D., Todorovic, V., Murtic, S., Klokic, I., Paradikovic, N., et al. 2017. Biostimulant prevents yield loss and reduces oxidative damage in tomato plants grown on reduced NPK nutrition. Journal of Plant Interactions 12:209-216. doi:10.1080/17429145.2017.1319503.

Kozak, M., Malarz, W., Serafin-Andrzejewska, M., and Kotecki, A. 2008. The effect of different sowing rate and Asahi SL treatment on soybean sowing value. p. 85-91. In Dąbrowski, Z.T. (ed.) Biostimulators in modern agriculture, field crops. Wieś Jutra, Waszawa, Poland.

Lakhdar, A., Iannelli, M.A., Debez, A., Massacci, A., Jedidi, N., and Abdelly, C. 2010. Effect of municipal solid waste compost and sewage sludge use on wheat (Triticum durum): growth, heavy metal accumulation, and antioxidant activity. Journal of the Science of Food and Agriculture 90:965-971. doi:10.1002/jsfa.3904.

Lamaison, J.L.C., et Carnet, A. 1990. Teneurs en principaux flavonoids des fleurs de Crataegeus monogyna Jacq et de Crataegeus laevigata (Poiret D.C.) en fonction de la vegetation. Pharmaceutica Acta Helvetiae 65:315-320.

Matysiak, K., and Kaczmarek, S. 2008. Potential advantages of Kelpak bioregulator applied to some field crops. p. 99-106. In Dąbrowski, Z.T. (ed.) Biostimulators in Modern Agriculture, Field Crops. Wieś Jutra, Waszawa, Poland.

Meier, U. 2001. Growth stages of mono- and dicotyledonous plants. $2^{\text {nd }}$ ed. Federal Biological Research Centre for Agriculture and Forestry, Braunschweig, Germany.

Michalak, I., Chojnacka, K., Dmytryk, A., Wilk, R., Gramza, M., and Rój, E. 2016. Evaluation of supercritical extracts of algae as biostimulants of plant growth in field trials. Frontiers in Plant Science 7:1591. doi:10.3389/fpls.2016.01591.

Michalek, W., Kocira, A., Findura, P., Szparaga, A., and Kocira, S. 2018. Wpływ biostymulatora Asahi SL na aktywność fotosyntetyczną wybranych odmian Phaseolus vulgaris L. Rocznik Ochrona Srodowiska 20:1286-1301.

Molmann, J.A.B., Steindal, A.L.H., Bengtsson, G.B., Seljasen, R., Lea, P., Skaret, J., et al. 2015. Effects of temperature and photoperiod on sensory quality and contents of glucosinolates, flavonols and vitamin $\mathrm{C}$ in broccoli florets. Food Chemistry 172:47-55. doi:10.1016/j.foodchem.2014.09.015.

Navabpour, S., Morris, K., Allen, R., Harrison, E., Mackerness, S.A.H., and Buchanan-Wollaston, V. 2003. Expression of senescence enhanced genes in response to oxidative stress. Journal of Experimental Botany 391:2285-2292.

Ochoa-Velasco, C.E., Valadez-Blanco, R., Salas-Coronado, R., Sustaita-Rivera, F., Hernández-Carlos, B., García-Ortega, S., et al. 2016. Effect of nitrogen fertilization and Bacillus licheniformis biofertilizer addition on the antioxidants compounds and antioxidant activity of greenhouse cultivated tomato fruits (Solanum lycopersicum L. var. Sheva). Scientia Horticulturae 201:338-345. doi:10.1016/j.scienta.2016.02.015 
Oltenacu, N., Iova, A.R., and Lascar, E. 2017. Researches on the influence of soil and climate conditions in the Romanian plain and technological chains on the capacity to maintain the apples quality-case study. Scientific Papers Series Management, Economic Engineering in Agriculture and Rural Development 17:231-236.

Pulido, R., Bravo, L., and Saura-Calixto, F. 2000. Antioxidant activity of dietary polyphenols as determined by a modified ferric reducing/antioxidant power assay. Journal of Agricultural and Food Chemistry 48:3396-3402. doi:10.1021/jf9913458.

Rathore, S.S., Chaudhary, D.R., Boricha, G.N., Ghosh, A., Bhatt, B.P., Zodape, S.T., et al. 2009. Effect of seaweed extract on the growth, yield and nutrient uptake of soybean (Glycine max) under rainfed conditions. South African Journal of Botany 75:351-355. doi:10.1016/j.sajb.2008.10.009.

Shan, B., Xie, J.-H., Zhu, J.-H., and Peng, Y. 2012. Ethanol modified supercritical carbon dioxide extraction of flavonoids from Momordica charantia L. and its antioxidant activity. Food and Bioproducts Processing 90:579-587. doi:10.1016/j.fbp.2011.09.004.

Sidhu, V., Nandwani, D., Wang, L., and Wu, Y. 2017. A study on organic tomatoes: Effect of a biostimulator on phytochemical and antioxidant activities. Journal of Food Quality 2017:ID5020742. doi:10.1155/2017/5020742.

Singleton, V., and Rossi, J. 1965. Colorimetry of total phenolics with phosphomolybdic-phosphotungstic acid reagents. American Journal of Enology and Viticulture 16:144-158.

Swieca, M., Gawlik-Dziki, U., Kowalczyk, D., and Zlotek, U. 2012. Impact of germination time and type of illumination on the antioxidant compounds and antioxidant capacity of Lens culinaris sprouts. Scientia Horticulturae 140:87-95. doi:10.1016/j.scienta.2012.04.005.

Szparaga, A., Kocira, S., Kocira, A., Czerwinska, E., Swieca, M., Lorencowicz, E., et al. 2018. Modification of growth, yield, and the nutraceutical and antioxidative potential of soybean through the use of synthetic biostimulants. Frontiers in Plant Science 9:1401. doi:10.3389/fpls.2018.01401.

Tarakhovskaya, E.R., Maslov, Y.I., and Shishova, M.F. 2007. Phytohormones in algae. Russian Journal of Plant Physiology 54:163-170. doi:10.1134/S1021443707020021.

Wójtowicz, A. 2012. The effect of biostimulator Terra-Sorb on winter rape yield. Episteme 15:243-250.

Zewail, R.M.Y. 2014. Effect of seaweed extract and amino acids on growth and productivity and some bioconstituents of common bean (Phaseolus vulgaris L.) plants. Journal of Plant Production 5:1441-1453.

Zimmermann, P., and Zentgraf, U. 2005. The correlation between oxidative stress and leaf senescence during plant development. Cellular and Molecular Biology Letters 10:515-534.

Zlotek, U., Szychowski, K.A., and Swieca, M. 2017. Potential in vitro antioxidant, anti-inflammatory, antidiabetic, and anticancer effect of arachidonic acid-elicited basil leaves. Journal of Functional Foods 36:290-299. doi:10.1016/j.jff.2017.07.024. 